\title{
Oil Prices and Government Bond Risk Premiums
}

\section{Hervé Alexandre and Antonin de Benoist*}

\begin{abstract}
This article analyses the impact of oil prices on bond risk premiums issued by emerging economies. No empirical study has yet focused on the effects of oil prices on government bond risk premiums. We develop a model of credit spread with data from the EMBIG index of 17 countries, from 1998 to 2008. An analysis in time series is carried out on each country and a panel analysis used to determine the global impact of oil prices on investors' risk perceptions. We suggest a new estimator for oil prices to take into account the effect of the price variance, and show that oil prices influence the risk premiums of sovereign bonds along with the price volatility that increases the accuracy of the model.
\end{abstract}

Keywords: Oil prices, sovereign debt, risk premium.

Classification: F30, G12, G15.

\section{Introduction}

For decades, government financing has been an increasing problem for countries worldwide. Globalization offers more ways of financing but also more uncertainty, particularly for countries with political problems or for those that do not fall within the most developed subsample.

Emerging economies such as Brazil or China have been developing steadily since the beginning of the 1990s. During this period, their issuing of government bonds has increased considerably, underlining their need for substantial investment in infrastructure and long-term projects. At the same time, they have had to face a series of financial crises, which has greatly reduced their credit capacity and increased the spread-and therefore the cost-of financing. The determinants of this spread and macroeconomic indicators alone cannot explain investors' perception of risk.

\footnotetext{
* The authors are based at the Université Paris-Dauphine in France and can be contacted at herve.alexandre@u-dauphine.fr. They are grateful to this article's referees for the latter's very helpful comments.
} 
Among the factors determining the risk associated with bonds, the price of oil price is a key element to be considered. As Edwards (1985) points out, nine of the ten last recessions have been preceded by oil crises. Moreover, the volatility of oil prices has strongly increased since January 1998. The impact of variations in oil price on economic performancegrowth, productivity, and inflation-has, therefore, been the subject of some empirical studies (see Blanchard \& Gali, 2007).

If international liquidity has been a subject of interest that has been well discussed in the financial literature, the impact of oil prices has not excited nearly the same interest. Min's (1998) article is, to our knowledge, the only study to include oil prices as an explanatory variable, but the author does not find significant links between variations in oil price and government bond spreads.

This article analyzes the impact of oil prices on the bond risk premiums issued by emerging economies. It is part of the wider framework of studies on the risk measure associated with foreign bonds (Edwards, 1985; Min, 1998; Pan \& Singleton, 2007). In spite of the multiplicity of works, however, it would seem that no empirical study has yet focused on the effects of oil prices on government bond risk premiums. In order to do so, we develop a model of credit spread ${ }^{1}$ with data from the emerging markets bond index global (EMBIG) of 17 countries from 1998 to 2008.

Our empirical study proceeds with three estimates. The first is an analysis of each country in time series to show how its individual characteristics influence the relation between oil prices and the risk premium of government bonds. The second is a panel analysis that examines the essential role of oil prices as a risk factor that is both global and external. The third is an improved variant of the panel analysis that confirms the essential role of the volatility of oil prices in estimating the risk associated with sovereign bonds.

\section{A Review of the Literature}

\subsection{Determinants of Risk Associated with Government Bonds}

The issuing of government bonds in emerging countries increased heavily during the 1990s, improving the liquidity of this financial product.

\footnotetext{
${ }^{1}$ This spread corresponds to the difference between the yield of a risky bond and that of one that is virtually risk-free, such as the treasury bills issued by the US.
} 
At present, government bonds are the first source of financing in developing countries, after foreign direct investment. At the same time the public debt market in developing countries has experienced serious upheavals following several financial crises. In these conditions, it is important to understand the factors determining the price of government bonds.

\subsubsection{Macroeconomic Determinants}

Different models allow for the selection of macroeconomic variables by modeling the borrowing status of a country. The principal indicators of solvency are (i) weak stock of debt, (ii) weak interest rate, and (iii) production growth. The economy's level of openness is another key factor in the international solvency of the country. Other variables of competitiveness, such as the exchange rate, can also play an important role in the country's credit risk.

One of the founding empirical studies on international credit markets is that of Edwards (1985), who is particularly interested in the measurement of government bonds in the context of the debt crises of the 1980s. The author develops a model that considers emerging countries as small borrowers within an almost perfect financial market: the spread depends on the default probability, which itself results from macroeconomic variables. The data comes from the World Bank and International Monetary Fund, and concerns 727 debt instruments of 19 of the least developed countries for the period 1976-1980. Several determinants are considered: (i) the ratio of investment growth as a percentage of gross domestic product (GDP), (ii) the average amount to be invested, (iii) the growth of GDP per unit of capital, (iv) the rate inflation, (v) international reserves, (vi) the deflation rate, and (vii) government spending added to GDP.

Edwards' (1985) empirical results show that the development of spread takes into account the economic characteristics particular to the country under consideration. For example, the debt-to-GDP ratio is positively correlated with the spread level. The sum of international reserves is significant and plays an important role in determining the amount of the risk premium. The proportion invested has a negative impact on default probability and the spread of government securities. The study shows that temporal differences within the same country are more important than differences between countries, and concludes that investors take into account a country's individual macroeconomic specificities. 
Cantor and Packer (1996) analyze the determinants of the spread of government bonds in over 49 countries in 1995, taking into account their GDP growth, inflation, current account, debt, indicators of economic development, and agency ratings (Moody's, Standard \& Poor's). The authors do not find any significant relationship between countries' macroeconomic indicators and the fluctuations in spread. A subsequent empirical study by Kamin and von Kleist (1999) analyzes more than 304 sovereign bonds issued in the 1990s. The authors find that the spread in Latin American countries is, on average, more than 39 percent higher than those in Asia, indicating a segmented government bonds market.

Min (1998) studies the economic determinants of the yield from government bonds (made out in American dollars) in emerging countries for the period 1991-1995. The determinants of default probability are regrouped into four groups of variables that explain the spread level: (i) liquidity and solvency, (ii) basic macroeconomics, (iii) variables of external shocks, and (iv) indicative variables. The results show that an economy's liquidity and solvency play an essential role through the GDPto-debt ratio and ratio of international reserves to GDP, and integrates the effect of external shocks on the country's risk of default. Most of the regional specificities considered are not significant, which indicates that common factors determine the spread level-this result is confirmed by recent studies such as that by Longstaff, Pan, Pedersen, and Singleton (2007). Finally, Min shows that the volatility of spread is symmetrically influenced both by liquidity and macroeconomic fundamentals such as the rate of inflation, the GDP-to-debt ratio, and the ratio of international reserves to GDP.

Following the increase in volatility of sovereign debt at the end of the 1990s, many investors appeared on the market to take advantage of investment opportunities. Ades, Kaune, Leme, Masih, and Tenengauzer (2000) first established an arbitration model on bond spreads issued in 15 emerging economies from 1996 to 2000. In the same way as Min (1998), Ades et al. break down the macroeconomic variables into four categories: (i) solvency (real gross national product [GNP]); (ii) liquidity (debt/public investment budget, international reserves, budgetary balance/GNP, and LIBOR); (iii) external shocks (exchange rate, exports/GNP); and (iv) indicative variables (previous default). From the evaluation model, it would seem that 12 of the 15 countries considered had undervalued bonds while only one country reached its basic value. 
Eichengreen and Mody (1998) analyze more than 1,300 bonds issued by 55 emerging economies between 1991 and 1997. The explanatory factors of the spread are the ten-year interest rate on American bonds, the ratio of external debt to GDP, the ratio of debt to exports, the ratio of international reserves to GDP, the level of growth to GDP, and finally the ratio of budget deficit to GDP. The authors' results confirm that an increase in the quality of a country's credit increases the probability of bond issuing, and reduces the government bond premium. The market differentiates between countries as a function of the quality of the borrower.

\subsubsection{Government Bonds: A Real Class of Assets?}

Is the risk associated with government bonds merely idiosyncratic or is it determined by global economic factors? To answer this question, Longstaff et al. (2007) examine the profile yield/risk of government bonds to analyze the associated credit risk determinants in the context of the capital asset pricing model. Their study concerns the monthly credit default swap (CDS) premiums made out in US dollars between October 2000 and May 2007 for each of the 26 countries studied. CDS premiums have the advantage of directly reflecting investors' risk perceptions. Moreover, the CDS government bonds market is often more liquid than the bonds market itself.

In order to analyze the determinants of the CDS sovereign bonds premium, the authors include four categories of explicative variables: (i) local variables (yield of local market, exchange rate, and sum of reserves); (ii) financial variables (stock market and American bonds market); (iii) variables of global risk premiums (yield of the Standard and Poor's (S\&P) 500 index and variation of the spread between historical volatility estimated on the options of the volatility index (VIX); and (iv) an investment flow variable.

Longstaff et al.'s (2007) results reveal a very strong correlation between the CDS premiums of the different countries. Three principal global factors explain 50 percent of their variation. The spread of CDS on government bonds depends on American shares (S\&P500 and NASDAQ indices), the bonds market, and a global risk premium. Pan and Singleton (2007) show that the spreads of different countries are strongly correlated with the VIX. The global risk, identical in the 26 countries, determines more than 30 percent of the total development of CDS spreads on government bonds. The macroeconomic determinants specific to each country represent only a small part of the total development of 
premiums. As in the work of Min (1998) or Ferrucci (2003), it seems that the risk premiums are higher in Latin America than in other regions.

\subsection{Impact of Oil Prices on Growth, Inflation, and Productivity}

\subsubsection{Oil Crises and Economic Performance: Empirical Evidence}

Economists have long examined the relationship between oil prices and macroeconomic performance. Since the 1970s and the growing dependence of oil-importing economies, many oil crises have occurred: the crash of 1986, the price increase of 1990/91 associated with the Gulf war, the growth of 2000, and the crisis of 2003 associated with the war in Iraq. In 2007/08, oil prices rose strongly as the result of a conjunction of economic, political, geological, and climatic factors. Thus, oil price variations depend to a large extent on exogenous events, such as those linked to the political situation in the Middle East, the development of cartels, or military conflicts.

Increases in oil price are deemed responsible for recessions, inflation, and the reduction in productivity of the mid-1970s. Numerous empirical studies such as that of Hamilton (1983) show that the relationship between oil prices and GDP is more than a simple statistical coincidence. Determining the mechanisms by which oil prices affect macroeconomic conditions is essential to quantify the former's impact on a country's solvency and to measure the spread of sovereign bonds. Nevertheless, some economists have questioned this idea (see Barsky \& Kilian, 2004), arguing that macroeconomic variables partly determine fluctuations in oil price.

\subsubsection{How Oil Prices Influence Growth, Inflation, and Productivity}

Effect of Energy Consumption on GDP

The elasticity of production to energy prices depends on the proportion of energy being used in production. Empirically, this proportion is relatively small. For example, in 2000, the US's consumption of oil-which reached 7.2 million barrels-represented only 2.2 percent of GDP. However, it is important to point out that this percentage has risen substantially following recent rises in oil price, although it remains small relative to production.

Nevertheless, the relations of cause and effect between variations in oil price and GDP are all but simple. Bohi (1991) shows that there is no 
empirical evidence to support the idea that countries with higher energy costs are more severely affected by an oil crisis than those that rely less on oil as a source of energy. Empirical studies show that the cost of an oil crisis is not so much the result of a rise in oil prices as that of a fall in the consumption of other factors of productions to which it leads. Rotemberg and Woodford (1996) show that a 10-percent increase in the oil price can lead to a 2.5-percent fall in GDP over an 18-month period.

\section{Sectoral Reallocations}

An oil crisis can have a different impact on capital and employment, and cause reallocations between sectors of activity. Hamilton (1983) shows that oil crises reduce demand in other industries, which leads to a redistribution of work between sectors of activity. The costs of capital adjustment and work, following an oil crisis, have been the subject of much research (see Lee, Ni, \& Ratti, 1995).

\section{Monetary Policies and Inflation}

Certain studies highlight the role of monetary policy in the relationship between oil prices and GDP. According to Barsky and Kilian (2004), the recession of 1973/74 was one of the consequences of the US Federal Reserve's monetary expansion in response to fears about inflation, which led to an increase in the oil price. Monetary policies can also cause inflationary spirals, wages-prices, caused by the oil price.

The macroeconomic effect of an increase in the oil price can potentially result in stagflation. This phenomenon is particularly important as an explanation of the crisis of the 1970s. As the rate of inflation is linked to monetary policy, the impact of an oil crisis depends primarily on the reaction of central banks to this economic shock. Hooker (2002) illustrates this phenomenon by showing that oil crises contributed significantly to inflation in the US up to 1981, the year in which the question of inflation became a priority of monetary policy.

\section{Modifications of Channel Transmissions}

While the economies of OECD countries have seen real variations in oil price in 2000 and 2003-which were as serious as the oil crises of 1973 and 1979-no variations in GDP or inflation were recorded. This calls into question the mechanisms put in place with regard to the relationship between oil prices and macroeconomic conditions. 
Blanchard and Gali (2007) confirm the hypothesis that oil prices influenced the stagflation of the 1970s, but point out that other effects were at work. Globally, economies-notably those of the OECD-are far less sensitive to fluctuations in the oil price. The impact of variations in the oil price on inflation has weakened. There may be several explanations for this. First, wage inflexibility has increased, which partly explains the reduced impact of oil price fluctuations. Second, central banks have actively adopted a policy of maintaining a low rate of inflation since the beginning of the 1980s (Herrera \& Pesavento, 2009). Finally, energy consumption and economies' dependence on oil have both dropped, even though there are disparities according to the country concerned.

\subsubsection{Oil Prices and Economic Risk: The Case of Oil-Producing Countries}

Most studies have focused on oil importing countries, but the relationship between economic growth and oil prices is radically different in an oil-producing country. Mechanically, an increase in the oil price should lead to an increase in GDP. This connection is, however, questioned by the efficiency of wealth redistribution systems and economic development models. Corden and Neary's (1982) "Dutch disease" model predicted that an important increase in oil revenues could damage the GDP of certain developing countries. This model was empirically backed up in oil-producing countries during the 1970s-the production of oil was developed to the detriment of the manufacturing and agricultural sectors.

It is certain that oil prices affect the credit risk of all governments. If the relationship between oil prices and macroeconomic performance has been developed since 1980, it remains significant. However, no empirical study has specifically examined the impact of oil prices on the spread of government bonds. This is the subject of the second part of our article.

\section{Empirical Study}

Our objective is to quantify the impact of the development of oil prices on the risk premium of government bonds. To do this, after presenting some descriptive statistics, we will proceed with an analysis in time series on each country considered, then to a panel analysis.

\subsection{Data Sources}

We use daily data on government bond spreads across 14 emerging countries and four regions (Latin America, the Middle East, 
Asia, and Africa). The data is obtained from DataStream and Reuters, and spans almost ten years from 1 January 1998 to 30 May 2008.

\subsubsection{Explained Variables}

The spread of government bonds refers to the risk premium that the bond-holder demands from the seller to hold the bond. For bonds issued at par, the spread corresponds to the difference between the bond's interest rate and the no-risk interest rate, here, the interest rate of bonds from the American treasury.

We use the EMBIG published by JP Morgan-an index of the spread of emerging countries' government bonds made out in US dollars. This index measures the difference between the premium paid by an emerging country and that of an American treasury bond of similar maturity. It is calculated from the average of all the bonds weighted by the capitalization of the bonds market. In contrast, the emerging markets bond index (EMBI) includes only liquid bonds, including Eurobonds and Brady bonds, whose minimum face value is USD500 million. The EMBIG's maturity period is longer than two and a half years, and covers more than 27 countries since 1998 (the EMBI covers only five countries from 1991 to 1995 and 11 since 1995).

Including the two series in the same empirical study creates a selection bias because the EMBI covers only Brady-type bond yields and the yields on certain structured instruments. Moreover, the two indices may yield different risk measurements because the composition of the two bond portfolios is different. We consider only the EMBIG, which is largely sufficient to bring the empirical estimation to a satisfactory conclusion. The EMBIG allows a more pertinent geographical analysis by region rather than by country. The indices by region are calculated as a geometrical average of the country indices.

\subsubsection{Explanatory Variables}

Our study draws on the models studied in the first part. The EMBIG makes it possible to obtain data gathered over several decades, which is not the case in most macroeconomic series. Following Longstaff et al. (2007), we include three sets of independent variables in our model: (i) market risk variables, (ii) exchange rates, and (iii) external shocks.

The market risk is interpreted by two indices: the Chicago Board Options Exchange VIX and the S\&P500 index. The VIX is a measure of the 
implicit volatility of a bond in the S\&P500 index, and concerns investors' perceptions of risk. An increase in the VIX is explained by an increase in the bonds spread. Pan and Singleton (2007) show that the premium bonds of different countries are strongly correlated to the VIX and, more generally, to the S\&P500 index, which is a factor of global risk. We assume that these two indices have positive impacts on the spread.

We include in our model the country's interest rate in dollar units (USD)—noted as FX-which reflects both the economy's competitiveness and the country's solvency. These two factors have a distinct impact on the spread. An increase in the exchange rate reduces the competitiveness of a country and increases the EMBIG, while an increase in the exchange rate increases the country's ability to fulfill its contract and thus reduce the bond risk premium.

External shocks are highlighted in this study by international liquidity and oil price. An increase in the interest rate increases the cost of new finance and debts that have already been contracted-a result confirmed by Eichengreen and Mody (1998). The impact of international liquidity is analyzed by the interest rate over a three-month period of US treasury bills, i.e., the short-term interest (STI), and by the ten-year or long-term interest (LTI) rate of US treasury bonds. As explained by the liquidity preference theory and shown empirically by Ferrucci (2003) and Kamin and von Kleist (1999), the impact of STI should be positive while that of LTI should be negative.

\subsubsection{Impact of Oil Prices}

We use the West Texas Intermediate (WTI) - also known as the Texas Light Sweet-to represent variations in the oil price. The WTI index is an index of light crude oil that serves as a yardstick for establishing the average oil price from the US. Economic theory suggests studying the real oil price rather than its nominal price. Nevertheless, while taking into account the wide range of fluctuations in oil price and the low inflation rate over the period considered, the choice to use the real price or nominal oil price does not interfere with the estimation of the spread. In the tradition of most empirical studies, our estimation adopts a nominal price level in logarithm form, noted as LN (WTI).

\subsection{Descriptive Statistics}

Tables 1 and 2 present a statistical description of the variables. 
Table 1: Statistical description of dependent variables

\begin{tabular}{lcccrcc}
\hline $\begin{array}{l}\text { Country or } \\
\text { region }\end{array}$ & Mean & Median & Max. & \multicolumn{1}{c}{ Min. } & $\begin{array}{r}\text { Standard } \\
\text { deviation }\end{array}$ & Observations \\
\hline Africa & 339.79 & 344.00 & 530.00 & 130.00 & 115.15 & 2,500 \\
Argentina & 111.07 & 104.00 & 194.00 & 46.00 & 41.62 & 2,500 \\
Asia & 218.45 & 219.00 & 340.00 & 100.00 & 66.41 & 2,500 \\
Brazil & 339.74 & 271.00 & 665.00 & 111.00 & 165.38 & 2,500 \\
Bulgaria & 505.59 & 542.00 & 745.00 & 182.00 & 150.12 & 2,500 \\
China & 217.84 & 233.00 & 301.00 & 136.00 & 47.72 & 2,500 \\
Colombia & 183.31 & 172.00 & 327.00 & 69.00 & 72.25 & 2,500 \\
Latin America & 239.77 & 211.00 & 382.00 & 116.00 & 75.03 & 2,500 \\
Mexico & 253.46 & 261.00 & 394.00 & 117.00 & 79.34 & 2,500 \\
Middle East & 162.99 & 165.00 & 255.00 & 99.00 & 46.12 & 2,499 \\
Nigeria & 344.26 & 328.00 & 539.00 & 136.00 & 144.25 & 2,500 \\
Panama & 428.93 & 408.00 & 712.00 & 198.00 & 144.49 & 2,500 \\
Poland & 269.33 & 282.00 & 387.00 & 162.00 & 62.23 & 2,500 \\
Russia & 342.74 & 379.00 & 627.00 & 25.00 & 185.45 & 2,500 \\
South Africa & 260.36 & 282.00 & 379.00 & 109.00 & 78.84 & 2,500 \\
Thailand & 160.25 & 175.00 & 194.00 & 74.00 & 34.35 & 2,500 \\
Turkey & 233.17 & 213.00 & 396.00 & 91.00 & 93.68 & 2,500 \\
Venezuela & 355.40 & 281.00 & 637.00 & 96.00 & 163.75 & 2,500 \\
\hline
\end{tabular}

Source: Authors' calculations.

The average differs greatly according to the country and the region. Therefore, with an average EMBIG of more than 509.59, the bonds issued by Bulgaria show the highest spread in the sample. Contrary to this, with an EMBIG average of 111.07, Argentina has the lowest spread of the countries and regions covered in this study. The variance is also very different according to the country. Argentina shows the weakest standard deviation, 41.62, while Russia shows the strongest at 185.45. Evidently, countries that have the highest average level of government bond spread have a particularly high variance. 
Table 2: Statistical description of independent variables

\begin{tabular}{lrrrrrc}
\hline Variable & \multicolumn{1}{c}{ Mean } & Median & Max. & Min. & $\begin{array}{c}\text { Standard } \\
\text { deviation }\end{array}$ & Observations \\
\hline WTI & 41.16 & 31.85 & 121.57 & 10.73 & 22.46 & 2,610 \\
VIX & 20.29 & 20.00 & 45.00 & 9.00 & 6.86 & 2,717 \\
S\&P500 & $1,217.88$ & $1,215.81$ & $1,565.15$ & 776.76 & 176.77 & 2,618 \\
STI & 3.53 & 3.94 & 6.42 & 0.61 & 1.71 & 2,584 \\
LTI & 6.62 & 6.46 & 9.09 & 4.16 & 1.02 & 2,717 \\
\hline
\end{tabular}

Note: $\mathrm{LTI}=$ long-term (30-year) interest rate, STI = short-term (three-month) interest rate. Source: Authors' calculations.

The short-term risk-free interest rate (STI, three-month maturity) is lower than the long-term risk-free interest rate (LTI, 30-year maturity). Carrying out a unit root test on each time series sample reveals that the government bonds spread is part of a first-order integration (1).

\subsection{Estimation and Interpretation}

\subsubsection{Analysis of Country/Regional Time Series}

Using a linear model with least squares estimation, we carry out a time series analysis of each country/region's government bond spread. This makes it possible to rely on the impact of the oil price on the EMBIG index on the country/region's idiosyncratic situation.

$$
\begin{aligned}
& \log \left(E M B I G_{i t}\right)-\log \left(E M B I G_{i t-1}\right)= \\
& \beta_{i 1}\left(S T I_{t}-S T I_{t-1}\right)+\beta_{i 2}\left(L T I_{t}-L T I_{t-1}\right)+\beta_{i 3}\left(V I X_{t}-V I X_{t-1}\right)+ \\
& \beta_{i 4}\left(S P 500_{t}-S P 500_{t-1}\right)+\beta_{i 5}\left(\log (W T I)_{t}-\log (W T I)_{t-1}\right)+\varepsilon_{i t}
\end{aligned}
$$

LTI is the long-term interest rate, STI is the short-term interest rate, WTI is the West Texas Intermediate index, and VIX is the Chicago Board Options Exchange volatility index. Table 3 presents the results of this model, that is to say, the impact of independent variables on the EMBIG logarithm.

The White test has a very weak p-value-we can thus reject the null hypothesis of homoscedasticity. The t-statistics presented are, therefore, adjusted by the White correction, making it possible to have a consistent covariance matrix estimator and a direct test for 
heteroscedasticity. The F-tests show that the groups of coefficients are significant at the threshold of 5 percent.

The oil price is a significant indicator of the global risk of external factors (Table 3). Most of the coefficients are positive and significant at the 5-percent level. Any increase in global risk has a knock-on effect on the bonds market. For example, the spread of a country such as Mexico increases in the case of a rise in the oil price. An increase in the oil price increases investors' perception of global risk, whatever the country's individual characteristics and EMBIG level.

In addition, the effect of the oil price differs greatly according to the country. Russia, Argentina, and Venezuela are three countries for which the impact of the oil price on spread is highest. An increase of 1 percent in the oil price manifests itself as an increase in the EMBIG of 0.04 percent in Russia and 0.03 percent in Venezuela. The oil price has a negative impact on the EMBIG for Asia, the Middle East, and countries such as China.

The results show that the development of oil prices has a different impact depending on the country studied. This difference could be explained by the fact that that certain countries import oil while others export it. An increase in the oil price constitutes a financial burden for the former and a benefit for the latter. For the borrowing countries, this transfer of wealth could have an impact on their default probability and the losses associated with it.

With regard to the other explanatory variables (VIX, S\&P500, STI, and LTI), our estimate partly confirms the empirical results reviewed in the first part of our study, with the exception of the VIX. This index of market risk has a coefficient that is negative most of the time and significantly so on the threshold of 5 percent. This result could be explained by the migration of investors toward government bonds, which are relatively low-risk following an increase in risk in the stock market. The influence of the S\&P500 index is positive and significant. The effect of the exchange rate on the EMBIG is negative and significant, seeming to indicate that an increase in the exchange rate is synonymous with an increase in solvency rather than a drop in competitiveness. Finally, the sign of the long-term interest rate concurs with Ferrucci's (2003) results. 
Table 3: Impact of independent variables on EMBIG

\begin{tabular}{|c|c|c|c|c|c|c|c|}
\hline \multirow{2}{*}{$\begin{array}{l}\text { Country or } \\
\text { region }\end{array}$} & \multicolumn{2}{|c|}{ Market risk } & \multirow[b]{2}{*}{ Exch. rate } & \multicolumn{3}{|c|}{ External shock } & \multirow{2}{*}{$\begin{array}{r}R^{2} \\
\text { adj. }\end{array}$} \\
\hline & S\&P500 & VIX & & WTI & LTI & STI & \\
\hline Africa & $\begin{array}{l}0.031^{* * *} \\
(2.80)\end{array}$ & $\begin{array}{l}-0.001^{* * *} \\
(-7.62)\end{array}$ & - & $\begin{array}{l}0.006^{*} \\
(1.86)\end{array}$ & $\begin{array}{l}-0.004 \\
(-1.58)\end{array}$ & $\begin{array}{l}-0.002 \\
(-0.99)\end{array}$ & 0.044 \\
\hline Argentina & $\begin{array}{l}0.048^{*} \\
(1.86)\end{array}$ & $\begin{array}{l}-0.002^{* * *} \\
(-9.42)\end{array}$ & $\begin{array}{l}-0.038^{* * *} \\
(-3.65)\end{array}$ & $\begin{array}{l}0.032^{* *} \\
(2.55)\end{array}$ & $\begin{array}{l}0.007 \\
(1.45)\end{array}$ & $\begin{array}{l}-0.015^{* * *} \\
(-3.06)\end{array}$ & 0.046 \\
\hline Asia & $\begin{array}{l}0.017^{* * *} \\
(2.58)\end{array}$ & $\begin{array}{l}0.000^{* * *} \\
(-4.75)\end{array}$ & - & $\begin{array}{l}-0.002 \\
(-0.52)\end{array}$ & $\begin{array}{l}-0.002 \\
(-1.59)\end{array}$ & $\begin{array}{l}-0.002^{*} \\
(-1.95)\end{array}$ & 0.004 \\
\hline Brazil & $\begin{array}{l}0.021 \\
(1.15)\end{array}$ & $\begin{array}{l}-0.002^{* * *} \\
(-14.04)\end{array}$ & $\begin{array}{l}-0.156^{* * *} \\
(-20.57)\end{array}$ & $\begin{array}{l}0.012^{* *} \\
(2.33)\end{array}$ & $\begin{array}{l}-0.004 \\
(-1.25)\end{array}$ & $\begin{array}{l}-0.007^{* *} \\
(-2.06)\end{array}$ & 0.211 \\
\hline Bulgaria & $\begin{array}{l}0.013 \\
(0.87)\end{array}$ & $\begin{array}{l}-0.001^{* * *} \\
(-10.80)\end{array}$ & - & $\begin{array}{l}0.010 \\
(1.33)\end{array}$ & $\begin{array}{l}-0.002 \\
(-0.77)\end{array}$ & $\begin{array}{l}-0.003 \\
(-1.18)\end{array}$ & 0.045 \\
\hline China & $\begin{array}{l}0.015^{* *} \\
(2.35)\end{array}$ & $\begin{array}{l}0.000^{* * *} \\
(4.44)\end{array}$ & & & $\begin{array}{l}-0.003^{* *} \\
(-2.53)\end{array}$ & $\begin{array}{l}0.001 \\
(0.66)\end{array}$ & 0.009 \\
\hline Colombia & $\begin{array}{l}0.027^{* *} \\
(2.03)\end{array}$ & $\begin{array}{l}-0.001^{* * *} \\
(-10.62)\end{array}$ & $\begin{array}{l}-0.010 \\
(-1.48)\end{array}$ & $\begin{array}{l}-0.010 \\
(-1.48)\end{array}$ & $\begin{array}{l}-0.002 \\
(-0.75)\end{array}$ & $\begin{array}{l}-0.003 \\
(-1.22)\end{array}$ & 0.043 \\
\hline $\begin{array}{l}\text { Latin } \\
\text { America }\end{array}$ & $-0.002^{* * *}$ & -0.015 & - & $0.015^{* *}$ & -0.004 & $-0.007^{* * *}$ & 0.081 \\
\hline & $(-14.38)$ & $(-1.11)$ & & $(2.24)$ & $(-1.42)$ & $(-2.61)$ & \\
\hline Middle East & $\begin{array}{l}-0.014^{* *} \\
(-2.18)\end{array}$ & $\begin{array}{l}0.000 \\
(-1.28)\end{array}$ & - & $\begin{array}{l}-0.021^{* * *} \\
(-2.59)\end{array}$ & $\begin{array}{l}-0.002 \\
(-1.61)\end{array}$ & $\begin{array}{l}-0.002^{* *} \\
(-2.03)\end{array}$ & 0.030 \\
\hline Mexico & $\begin{array}{l}-0.010 \\
(-1.16)\end{array}$ & $\begin{array}{l}-0.001^{* * *} \\
(-8.06)\end{array}$ & $\begin{array}{l}-0.034^{* * *} \\
(-17.51)\end{array}$ & $\begin{array}{l}0.007^{*} \\
(1.69)\end{array}$ & $\begin{array}{l}-0.003^{*} \\
(-1.95)\end{array}$ & $\begin{array}{l}-0.003^{* *} \\
(-2.05)\end{array}$ & 0.156 \\
\hline Nigeria & $\begin{array}{l}0.017 \\
(1.10)\end{array}$ & $\begin{array}{l}-0.001^{* * *} \\
(-5.78)\end{array}$ & - & & $\begin{array}{l}-0.007^{* *} \\
(-2.35)\end{array}$ & & 0.015 \\
\hline Panama & $\begin{array}{l}0.012 \\
(1.14)\end{array}$ & $\begin{array}{l}-0.001^{* * *} \\
(-10.31)\end{array}$ & - & $\begin{array}{l}0.021^{* * *} \\
(4.03)\end{array}$ & $\begin{array}{l}0.002 \\
(1.16)\end{array}$ & $\begin{array}{l}0.002 \\
(0.96)\end{array}$ & 0.044 \\
\hline Poland & $\begin{array}{l}0.012 \\
(1.58)\end{array}$ & $\begin{array}{l}0.000^{* * *} \\
(-4.95)\end{array}$ & $\begin{array}{l}-0.029^{* * *} \\
(-8.17)\end{array}$ & $\begin{array}{l}-0.008^{* *} \\
(-2.13)\end{array}$ & $\begin{array}{l}-0.002 \\
(-1.38)\end{array}$ & $\begin{array}{l}0.002^{* *} \\
(2.29)\end{array}$ & 0.037 \\
\hline Russia & $\begin{array}{l}-0.038 \\
(-1.18)\end{array}$ & $\begin{array}{l}-0.002^{* * *} \\
(-8.09)\end{array}$ & $\begin{array}{l}-0.011^{* * *} \\
(-8.76)\end{array}$ & $\begin{array}{l}0.040^{* *} \\
(2.54)\end{array}$ & $\begin{array}{l}-0.006 \\
(-0.88)\end{array}$ & $\begin{array}{l}0.008 \\
(1.26)\end{array}$ & 0.058 \\
\hline S. Africa & $\begin{array}{l}0.038^{* * *} \\
(3.32)\end{array}$ & $\begin{array}{l}0.000 \\
(1.57)\end{array}$ & $\begin{array}{l}-0.010^{* * * *} \\
(-5.96)\end{array}$ & $\begin{array}{l}0.012^{* *} \\
(2.14)\end{array}$ & $\begin{array}{l}0.001 \\
(0.41)\end{array}$ & $\begin{array}{l}0.003 \\
(1.46)\end{array}$ & 0.018 \\
\hline Thailand & $\begin{array}{l}0.024^{* *} \\
(2.41)\end{array}$ & $\begin{array}{l}0.000^{* * *} \\
(-3.65)\end{array}$ & $\begin{array}{l}-0.002^{* * *} \\
(-3.02)\end{array}$ & $\begin{array}{l}-0.007 \\
(-1.33)\end{array}$ & $\begin{array}{l}-0.006^{* * * *} \\
(-2.86)\end{array}$ & $\begin{array}{l}-0.001 \\
(-0.59)\end{array}$ & 0.014 \\
\hline Turkey & $\begin{array}{l}0.036^{* *} \\
(2.29)\end{array}$ & $\begin{array}{l}-0.001^{* * *} \\
(-5.11)\end{array}$ & $\begin{array}{l}-0.177^{* * *} \\
(-14.84)\end{array}$ & $\begin{array}{l}0.010 \\
(1.28)\end{array}$ & $\begin{array}{l}-0.008^{* *} \\
(-2.44)\end{array}$ & $\begin{array}{l}0.007^{* *} \\
(2.42)\end{array}$ & 0.099 \\
\hline Venezuela & $\begin{array}{l}-0.031 \\
(-1.66)\end{array}$ & $\begin{array}{l}-0.002^{* * *} \\
(-12.04)\end{array}$ & - & $\begin{array}{l}0.026^{* * *} \\
(2.93)\end{array}$ & $\begin{array}{l}-0.006 \\
(-1.57)\end{array}$ & $\begin{array}{l}-0.006 \\
(-1.61)\end{array}$ & 0.060 \\
\hline
\end{tabular}

Note: LTI = long-term (30-year) interest rate, STI = short-term (three-month) interest rate. Adjusted t-statistics of White correction are given in parentheses below coefficients. Asterisks ${ }^{*}{ }^{* *}$, and ${ }^{* * *}$ indicate significance at 90,95 , and 99 percent, respectively.

Source: Authors' calculations. 


\subsubsection{Panel Analysis}

The previous study gives an insight into the individual impact of oil prices on a country's EMBIG. It would be interesting to design a model that could quantify this impact from a global point of view. The question would be, therefore, to know what effect an increase in the oil price could have on the spread of government bonds.

The data we have used for this study includes more than 17 countries and regions, and has been recorded on a daily basis over almost ten years from January 1998 to April 2008. A panel analysis was necessary to improve the results. Model 2 takes the following form:

$$
\begin{aligned}
& \log \left[E M B I G_{i t}\right]=\alpha_{i}+\beta_{1} S T I_{i t}+\beta_{2} L T I_{i t}+\beta_{3} V I X_{i t}+ \\
& \left.\beta_{4} S P 500_{i t}+\beta_{5} \log (W T I)_{i t}\right)+\varepsilon_{i t}
\end{aligned}
$$

The number of observations is 25,669 and the number of groups, 17 . Table 4 presents the results of our panel analysis. All the coefficients are significant at 5 percent. In the case of a fixed effects model, the most relevant $\mathrm{R}^{2}$ value is the $\mathrm{R}^{2}$ within because it gives an idea of the intra-individual share of the dependent variable explained by the explanatory variables. The $\mathrm{R}^{2}$ within is 0.6396 , which is very satisfactory. The $\mathrm{R}^{2}$ between $(0.1044)$ gives an idea of the contribution of fixed effects to the model.

In order to determine which of the two models is the most relevant, we revert to the Haussmann test's hypotheses:

- H0: The random models are equivalent.

- Ha: The fixed effects model is better than the random effects model.

Applying this test makes it possible to reject the null hypothesis according to which the models are equivalent. Here, the most relevant model is the fixed effects model. If the test makes it possible to categorize between the two models, the model carried over must depend on other, more theoretical, considerations. Allowing for the existence of random effects returns to the supposition that the factor representing the individual effects is not correlated with the explanatory variables. This hypothesis is particularly strong for our model and, consequently, the fixed effects model is the more appropriate one for our study. 
The panel analysis shows that the oil price has a significant effect on the EMBIG. An increase of 1 percent in the former brings about an increase of 0.298 percent in the spread. The coefficient of the oil price is significant at 1 percent. The development of the oil price is a factor of global and external risk, which influences the cost of credit for governments.

Table 4: Results of panel analysis 2(a)

\begin{tabular}{lcc}
\hline \multicolumn{3}{c}{ Explained variable: (EMBIG) log } \\
\hline Explanatory variables & Random effects model & Fixed effects model \\
\hline Constant & $4.90169^{* * *}$ & $4.90171^{* * *}$ \\
& $(-58.47)$ & $(150.63)$ \\
STI & $-0.02093^{* * *}$ & $-0.02093^{* * *}$ \\
& $(-11.32)$ & $(-11.32)$ \\
LTI & $-0.04473^{* * *}$ & $-0.04473^{* * *}$ \\
& $(-7.36)$ & $(-7.36)$ \\
S\&P500 & $0.00016^{* * *}$ & $0.00016^{* * *}$ \\
& $(8.48)$ & $(8.48)$ \\
VIX & $0.00265^{* * *}$ & $0.00265^{* * *}$ \\
& $(6.45)$ & $(6.45)$ \\
Log (WTI) & $0.29838^{* * *}$ & $0.29838^{* * *}$ \\
& $(96.68)$ & $(96.69)$ \\
$\sigma$ & 0.31851 & 0.32599 \\
Error & 0.29196 & 0.29196 \\
$\mathrm{R}^{2}$ within & 0.63960 & 0.63960 \\
$\mathrm{R}^{2}$ between & 0.10440 & 0.10440 \\
Observations & 25,669 & 25,669 \\
\hline
\end{tabular}

Note: $\mathrm{LTI}=$ long-term (30-year) interest rate, STI = short-term (three-month) interest rate, $\sigma=$ random effects/fixed effects. T-statistics are given in parentheses below coefficients. Asterisks ${ }^{* * *}$ indicate significance at 1 percent.

Source: Authors' calculations.

With regard to the other explanatory variables, the empirical study rejoins the results suggested by theory and empirical literature. As Ferrucci (2003) shows, long-term interest rates have a weaker impact than short-term rates. The VIX has a positive and significant effect on the EMBIG, while the S\&P500 index has a relatively weak effect on the explanatory variable. This can be explained by the fact that market risk is already represented by the volatility of the options of the S\&P500 index, graded VIX. Finally, $\sigma$ corresponds, respectively, to the fixed effects and random effects of the models. 
Numerous empirical studies, such as that of Blanchard and Gali (2007), have shown that the effect of oil prices on macroeconomic performance has dropped significantly since the 1980s. Some studies explain this development as being the result of an increase in the variance of the oil price. In the following panel analysis, the empirical study constructs an index of oil price corrected for volatility. The literature review has shown that the impact of a rise in oil prices on economic activity has dropped since the 1980s. In fact, it is the mechanisms of transmission of oil crises on economic performance that have changed. The literature shows the important role of the volatility of oil prices on a country's economic growth.

Lee et al. (1995) show that the relationship between economic growth and oil price was no longer significant after 1986. The authors defend the idea that oil prices have not lost their effect on GDP if one takes into account the extent of variations in oil price. Crises relating to oil prices are more likely to affect economic performance in an environment of stable oil prices than in one where oil price movements are erratic.

Lee et al. (1995) develop an indicator of the oil price corrected of its variance, and note that this indicator significantly influences macroeconomic performances regardless of the period under consideration. This result concurs with the idea that the impact of oil prices on economic activity is different according to whether or not it is anticipated. Following the example of empirical studies such as Hamilton (1997), Lee et al. state that the effect of oil price is asymmetrical: an increase in oil price is associated with a significant drop in GNP, while a drop in price is not significantly linked to economic activity. This is why we use a positive semi-variance.

In our study, we put in place an indicator that concurs with the empirical results on the nature of the impact of oil prices on economic activity. From this point of view, the indicator appears as a risk premium of oil that takes into account the volatility of oil prices. This variable, denoted as "prime WTI," is defined by the relationship between the yield of the WTI index and a positive three-month semi-variance.

$$
\text { PrimeWTI }=\frac{W T I}{T^{-1} \sum\left(\left(W T I_{t}-\overline{W T I}\right)^{2}\right) \cdot I\left(W T I_{t}>\overline{W T I}\right)}
$$


An increase in the oil price is just as likely to influence the risk premium of government bonds because its variance is weak. This leads us to conclude that such a variable has a positive and significant impact on the measurement of government bonds spread.

We then proceed to a panel analysis, the results of which are shown in Table 5. The method of estimation adopted is similar to that of the analysis in the previous panel. The $\mathrm{R}^{2}$ within and between indicates that the independent variables explain more than 66 percent of the fluctuation in the EMBIG. The $\mathrm{R}^{2}$ both within and between is higher than in model 2(a). The coefficients are all individually significant at 5 percent except the S\&P500. The latter has no effect on the risk perception of sovereign bonds. The coefficient of the new indicator of the variations in oil price, denoted by "prime WTI," is particularly high and significant on the threshold of 1 percent.

Table 5: Results of panel analysis 2(b)

\begin{tabular}{lcc}
\hline \multicolumn{3}{c}{ Explained variables: (EMBIG) log } \\
\hline \multicolumn{1}{c}{ Explanatory variables } & Random effects model & Fixed effects model \\
\hline Constant & $4.20574^{* * *}$ & $4.20576^{* * *}$ \\
STI & $(122.37)$ & $(49.74)$ \\
& $-0.02365^{* * *}$ & $-0.02365^{* * *}$ \\
LTI & $(-13.23)$ & $(-13.23)$ \\
& $-0.12707^{* * *}$ & $-0.12707^{* * *}$ \\
S\&P500 & $(-24,99)$ & $(-24,99)$ \\
& 0.00001 & 0.00001 \\
VIX & $(0.39)$ & $(0.39)$ \\
& $0.00352^{* * *}$ & $0.00352^{* * *}$ \\
WTI premium & $(7.69)$ & $(7.69)$ \\
& $0.56223^{* * *}$ & $0.56223^{* * *}$ \\
$\sigma$ & $(108.19)$ & $(108.19)$ \\
Error & 0.31852 & 0.32600 \\
R $^{2}$ within & 0.28260 & 0.28260 \\
R $^{2}$ between & 0.66240 & 0.66240 \\
Observations & 0.10440 & 0.10440 \\
\hline
\end{tabular}

Note: $\mathrm{LTI}=$ long-term (30-year) interest rate, STI = short-term (three-month) interest rate, $\sigma=$ random effects $/$ fixed effects. T-statistics are given in parentheses below coefficients. Asterisks ${ }^{* * *}$ indicate significance at 1 percent.

Source: Authors' calculations. 
According to model 2(b), a 1-percent increase in the ratio of the oil price to its variance causes an increase of 0.5622 percent on the EMBIG. This model validates the theory according to which the variance of the oil price plays a determining role in measuring the risk associated with government bonds. Correcting the oil price by its semi-variance makes it possible to obtain better estimates.

\section{Conclusion}

Oil prices represent a global risk factor likely to influence countries' credit risk. This analysis is the first to demonstrate the significant effect of oil price variations on the bond spread of a country.

The empirical study proceeds firstly with an analysis in time series of each of the 17 countries from January 1998 to 2008. The models developed concur with the theoretical models. Also, the impact of the oil price on the risk associated with government bonds depends on the individual characteristics of the country considered.

Second, we analyze the impact of oil prices on the EMBIG as a factor of global risk. This explains the use of a panel analysis. The estimate means used is a fixed effects model. Oil prices have a positive and significant impact on the risk premiums of government bonds. An increase of 1 percent in oil price increases the EMBIG by 0.26 percent.

Third, the panel analysis uses an indicator that corrects oil price volatility. This indicator is justified by the argument that many empirical studies underline the importance of oil price volatility to the relationship between oil prices and macroeconomic performance. An increase of 1 per cent in the oil price leads to an increase of 0.56 per cent in the EMBIG. From these results, it seems that the first panel analysis underestimates the real impact of the oil price on government bond risks.

In terms of the overall picture, we show that oil prices significantly influence the risk premiums of sovereign obligations. Including this variable in the measurement models of risk associated with government bonds is, therefore, clearly justified. 


\section{References}

Ades, A., Kaune, F., Leme, P., Masih, R., \& Tenengauzer, D. (2000). A new framework for assessing fair value in emerging market hard currency debt (Global Economics Paper No. 45). New York, NY: Goldman Sachs Group.

Barsky, R., \& Kilian, L. (2004). Oil and the macroeconomy since 1970 (Discussion Paper No. 4496). London, UK: Centre for Economic Policy Research.

Blanchard, O., \& Gali, J. (2007). Monetary policy, labor market, rigidity and oil price shock. Paris: Banque de France Foundation for Monetary, Financial and Banking Economic Research.

Bohi, D. R. (1991). On the macroeconomic effects of energy price shocks. Resources and Energy, 13, 145-162.

Cantor, R., \& Packer, F. (1996). Determinants and impact of sovereign credit ratings. Federal Reserve Bank of New York Economic Policy Review, 2, 37-53.

Corden, W. M., \& Neary, J. P. (1982). Booming sector and deindustrialization in a small open economy. Economic Journal, 92(368), 825-848.

Edwards, S. (1985). LDCs' foreign borrowing and default risk: An empirical investigation, 1976-1980. American Economic Review, $74(4), 726-734$.

Eichengreen, B., \& Mody, A. (1998). What explains changing spreads on EM debt: fundamentals or market sentiment? (Working Paper No. 6408). Cambridge, MA: National Bureau of Economic Research.

Ferrucci, G. (2003). Empirical determinants of emerging market economies' sovereign bond spreads (Working Paper No. 205). London, UK: Bank of England.

Hamilton, J. D. (1983). Oil and the macroeconomy since World War II. Journal of Political Economy, 91, 228-248.

Hamilton, J. D. (1997). Measuring the liquidity effect. American Economic Review, 87(1), 80-97. 
Herrera, A. M., \& Pesavento, E. (2009). Oil price shocks, systematic monetary policy, and the "Great Moderation." Macroeconomic Dynamics, 13(1), 107-137.

Hooker, M. A. (2002). Are oil shocks inflationary? Asymmetric and nonlinear specifications versus changes in regime. Journal of Money, Credit and Banking, 34, 540-561.

Kamin, S. B., \& von Kleist, K. (1999). The evolution and determinants of EM credit spreads in the 1990s (International Finance Discussion Paper No. 653). New York, NY: Federal Reserve Bank of New York.

Lee, K., Ni, S., \& Ratti, R. A. (1995). Oil shocks and the macroeconomy: The role of price variability. Energy Journal, 16, 39-56.

Longstaff, F. A., Pan, J., Pedersen, L. H., \& Singleton, K. J. (2007). How sovereign is sovereign credit risk? (Working Paper No. 13658). Cambridge, MA: National Bureau of Economic Research.

Min, H.-G. (1998). Determinants of emerging market bond spread: Do economic fundamentals matter? (Policy Research Working Paper No. 1899). Washington, DC: World Bank.

Pan, J., \& Singleton, K. J. (2007). Default and recovery implicit in the term structure of sovereign CDS spreads. Retrieved from http://www.mit.edu/ junpan/sovrev.pdf.

Rotemberg, J. J., \& Woodford, M. (1996). Imperfect competition and the effects of energy price increases. Journal of Money, Credit and Banking, 28 (Part 1), 549-577. 